\title{
ENTRE A OBRIGAÇÃO E O PRAZER DE CRIAR: UMA ANÁLISE PSICODINÂMICA DO PRAZER-SOFRIMENTO NO TRABALHO ARTÍSTICO ${ }^{1}$
}

\author{
Monique Nascimento ${ }^{2}$
}

Eloise Helena Livramento Dellagnelo ${ }^{3}$

http://dx.doi.org/10.1590/1413-2311.205.80531

\section{RESUMO}

Nos debates atuais, o artista tem sido considerado como um possível trabalhador do futuro, um sujeito intrinsecamente motivado. Entretanto, observamos que tal perspectiva de análise concebe a arte e a atividade artística de maneira romantizada, e que tende a mascarar condições reais de tal atividade de trabalho. Diante do exposto, desenvolvemos um estudo com o intuito de compreender e analisar as possíveis relações existentes entre o contexto de trabalho artístico na região da grande Florianópolis/SC, e vivências de prazer-sofrimento dos trabalhadores nele inseridos, tendo em vista o processo de mercantilização da cultura. Para tanto, utilizamos como arcabouço teórico a Psicodinâmica do Trabalho. Participaram desta pesquisa, ocorrida entre os meses de setembro a dezembro de 2016, quatro artistas atuantes na região da grande Florianópolis. Após a delimitação dos participantes, realizamos com cada sujeito, três entrevistas semiestruturadas individuais em profundidade e observações de suas rotinas de trabalho. As entrevistas foram gravadas, transcritas e submetidas à análise de conteúdo categorial temática, proposta por Bardin (2016). Concluímos que o contexto de trabalho artístico pode possibilitar tanto a vivência de prazer quanto de sofrimento ao artista. Todavia, observamos uma possibilidade de intensificação do sofrimento no trabalho, influenciada pela maior aproximação dos artistas à lógica mercadológica.

\footnotetext{
${ }^{1}$ Recebido em 23/02/2018, aceito para publicação em 02/07/2018.

${ }^{2}$ Universidade Federal de Santa Catarina (Florianópolis, SC, Brasil)-moniquenn@gmail.com

${ }^{3}$ Universidade Federal de Santa Catarina (Florianópolis, SC, Brasil) - eloise.livramento@ufsc.br
} 
Palavras-chave: Trabalho Artístico. Prazer e Sofrimento no Trabalho. Mercantilização da Cultura.

\title{
BETWEEN THE OBLIGATION AND THE PLEASURE TO CREATE: A PSYCHODYNAMIC ANALYSIS OF PLEASURE-SUFFERING IN ARTISTIC WORK
}

\begin{abstract}
In today's debates, the artist has been considered as a possible worker of the future, an intrinsically motivated subject. However, we observe that this perspective of analysis conceives art and art activity in a romanticized way and tends to mask the real conditions of such work activity. In view of the above, we have developed a study with the purpose of understanding and analyzing the possible relationships between the artistic work context in the region of Florianópolis, and experiences of pleasure and suffering of the workers included in it, considering the process of commodification of culture. For this, we use as theoretical framework of the Psychodynamics of Work. Participated in this research, which occurred between September and December 2016, four artists working in the region of Greater Florianópolis. After delimiting the participants, we performed with each subject, three individual semi-structured interviews in depth and observations of their work routines. The interviews were recorded, transcribed and submitted to the analysis of thematic categorical content proposed by Bardin (2016). We conclude that the context of artistic work can enable both the experiencing of pleasure and suffering to the artist. However, we observe a possibility of intensification of suffering at work, influenced by the greater approximation of artists to the marketing logic.
\end{abstract}

Key words: Artistic Work. Pleasure and Suffering at Work. Commodification of Culture.

\author{
ENTRE LA OBLIGACIÓN Y EL PLACER DE CREAR: UN ANÁLISIS \\ PSICODINÁMICO DEL PLACER-SUFRIMIENTO EN EL TRABAJO ARTÍSTICO
}

\section{RESUMEN}


En los debates actuales, el artista ha sido considerado como un posible trabajador del futuro, un sujeto intrínsecamente motivado. Sin embargo, observamos que tal perspectiva de análisis concibe el arte y la actividad artística de manera romantizada, y que tiende a enmascarar condiciones reales de tal actividad de trabajo. En el marco de lo expuesto, desarrollamos un estudio con el intuito de comprender y analizar las posibles relaciones existentes entre el contexto de trabajo artístico en la región de la gran Florianópolis, y vivencias de placersufrimiento de los trabajadores en él insertados, teniendo en vista el proceso de mercantilización de la cultura. Para ello, utilizamos como marco teórico de la Psicodinámica del Trabajo. Participaron de esta investigación, ocurrida entre los meses de septiembre a diciembre de 2016, cuatro artistas actuantes en la región de la gran Florianópolis. Después de la delimitación de los participantes, realizamos con cada sujeto, tres entrevistas semiestructuradas individuales en profundidad y observaciones de sus rutinas de trabajo. Las entrevistas fueron grabadas, transcritas y sometidas al análisis de contenido categorial temático, propuesta por Bardin (2016). Concluimos que el contexto de trabajo artístico puede posibilitar tanto la vivencia de placer y de sufrimiento al artista. Sin embargo, observamos una posibilidad de intensificación del sufrimiento en el trabajo, influenciada por la mayor aproximación de los artistas a la lógica mercadológica.

Palabras-claves: Trabajo artístico. Placer y Sufrimiento en el trabajo. Mercantilización de la Cultura.

\section{INTRODUÇÃO}

Em circunstâncias em que inúmeros países têm enfrentado o aumento do desemprego estrutural, e que recentemente a cultura passou a ser vislumbrada como vetor de desenvolvimento econômico (THROSBY, 2001; BENHAMOU, 2007), tem emergido nos últimos anos, um interesse no setor cultural, de maneira especial, em seu potencial para geração de emprego. Não obstante, apesar desse movimento crescente, percebemos que há uma série de desafios associados à compreensão do artista enquanto trabalhador.

Frequentemente, a atividade artística é associada à genialidade, ao prazer, ao lazer e ao ócio, e o artista é considerado como um possível trabalhador do futuro, uma figura excepcional, criativa, móvel perante às hierarquias, um empreendedor, um empresário de si mesmo, intrinsecamente motivado. Tal perspectiva de análise insiste no caráter extra econômico da atividade artística, sendo a arte vislumbrada como inspiração pura e a atividade 
artística contemplada romanticamente como forma idealmente desejável de trabalho. Diante de tais pressupostos, presumimos que a ideologia utópica e romântica do trabalho artístico mascara a existência de aspectos reais de uma carreira (ANTUNES, 2015; MARX, [1844]2017; MENGER, 2005; BENDASSOLLI; BORGES-ANDRADE，2011; BANKS; GILL; TAYLOR, 2013; HOPE; RICHARDS, 2015).

No que concerne a esses aspectos relacionados ao trabalho artístico, autores como Menger (2005), Bendassolli (2009), Transform (2008), Benhamou (2007), Banks, Gill e Taylor (2013) e Loacker (2013) elucidam que via de regra, são formas de emprego precarizados, temporários - incluindo-se projetos ou contratos de trabalho com vários clientes ao mesmo tempo -, com poucos benefícios trabalhistas, e cujo tempo de trabalho e o tempo livre não possuem fronteiras definidas. Destacamos ainda, que os artistas experimentam grandes desigualdades e variabilidades de renda.

Frente a tais condições de trabalho, cabe refletir a respeito da relação existente entre a subjetividade dos artistas e seu trabalho. Para Dejours (2012b), nenhuma relação de trabalho pode ser considerada neutra no que se refere à subjetividade do trabalhador. Pelo contrário, ou o trabalho pode promover o que há de melhor, repercutindo em favor da autorrealização ou da construção da identidade, ou pode causar a desestabilização psíquica. Nesse sentido, o trabalho pode ser para o trabalhador, tanto fonte de prazer quanto de sofrimento.

Salientamos que trabalhos sobre as vivências de prazer-sofrimento e contexto de trabalho artístico são escassos. Monteiro, Moraes, Mendes e Merlo (2017) organizaram um livro que comemora a prática de 10 anos da Psicodinâmica do Trabalho no Brasil. Nesta obra, foi realizado o levantamento e análise de pesquisas em Psicodinâmica nas cinco regiões brasileiras - norte, nordeste, centro-oeste, sudeste, sul. Diante do levantamento empreendido, foram apontadas algumas investigações concernentes ao trabalho artístico, provenientes das áreas da psicologia e fisioterapia. As áreas da arte contempladas pelas pesquisas foram: música (ALVARENGA, 2013; ASSIS, 2008), dança (SANTOS, 2008; SEGNINI, 2010; SEGNINI; LANCMAN, 2011), literatura (BUENO, 2012; FERREIRA, 2011a, 2011b), e teatro (PIRES, 2011; LIMA, 2009) ${ }^{4}$.

Nesse sentido, percebemos que apesar do processo de mercantilização da cultura não ser algo recente, estudos que relacionem vivências de prazer-sofrimento no trabalho artístico ao processo de mercantilização são praticamente inexistentes, principalmente nos estudos

\footnotetext{
${ }^{4}$ Destacamos que não foram encontrados estudos que se utilizassem da psicodinâmica do trabalho para investigação da influência do processo de mercantilização da cultura nas vivências de prazer-sofrimento dos artistas enquanto trabalhadores, nas diversas áreas de conhecimento.
} 
organizacionais. Todavia, ao observarmos que a compreensão de que a cultura, bem como as artes em geral, correspondem, por essência, a um campo da experiência humana que lida com valores simbólicos, e não necessariamente econômicos (BENDASSOLLI; BORGESANDRADE, 2011), nos cabe questionar se as artes se constituem como uma esfera de trabalho diferente dos mundos de produção, ou se o desenvolvimento das atividades artísticas obedece às mesmas regras econômicas, com alguns ajustes (MENGER, 2005).

Ressaltamos que o aporte teórico da psicodinâmica do trabalho, oferece uma grande contribuição ao estudo da relação entre subjetividade e trabalho, ao buscar compreender a maneira como os trabalhadores subjetivam às vivencias de prazer e sofrimento no trabalho, $\mathrm{o}$ sentido que dão a elas, e o uso de estratégias defensivas (MENDES, 2007). Assim, o trabalho artístico, essencialmente marcado pela flexibilidade, e por incertezas (MENGER, 2005; BENHAMOU, 2007), pode ser vislumbrado como um campo de estudos privilegiado para a investigação das vivências de prazer e sofrimento, oferecendo contribuições para o arcabouço teórico da psicodinâmica do trabalho, e para a existência de análises que compreendam a dinâmica da esfera artística e que apontem suas contradições.

Diante desse contexto, destacamos a relevância do presente trabalho, uma vez que o mesmo se concentra, na compreensão e análise de como ocorrem as vivências de prazersofrimento e o contexto de trabalho artístico na região da grande Florianópolis, tendo em vista o processo de mercantilização da cultura. Para a compreensão do fenômeno proposto, buscaremos versar, a seguir, a respeito do contexto de trabalho artístico nas sociedades centradas no mercado. Posteriormente, apresentaremos as bases teóricas e reflexões em psicodinâmica do trabalho que nortearam esta pesquisa. Buscaremos também, elucidar a respeito das especificidades metodológicas desta investigação. Transcorreremos, ainda, a respeito das vivências de prazer-sofrimento e do contexto de trabalho artístico na região da grande Florianópolis, tendo em vista o processo de mercantilização da cultura, a partir da experiência vivida por Luiz, Equilibrista, Fernando e Ricardo. Por fim, apresentamos algumas reflexões concernentes à problemática que esta investigação propõe: Como ocorrem as vivências de prazer-sofrimento e o contexto de trabalho artístico na região da grande Florianópolis, tendo em vista o processo de mercantilização da cultura?

\section{O TRABALHO ARTÍSTICO NAS SOCIEDADES CENTRADAS NO MERCADO}

A consolidação da noção de economia como um sinônimo para o mercado autorregulado (POLANY, 2000), fez com que lhe fossem subordinadas todas as formas de 
manifestação humana, e com a produção da área da cultura não foi diferente (BRANT, 2009). Nesse sentido, podemos afirmar que a atividade artística não permaneceu imune à unidimensionalidade do sistema social contemporâneo, como diria Ramos (1989). Em trabalhos desenvolvidos nas duas últimas décadas (MENGER, 2005; TRANSFORM, 2008; LOACKER, 2013; BENDASSOLLI; BORGES-ANDRADE, 2011), vislumbramos uma série de mudanças que tiveram um relevante impacto na forma de fazer cultura, e também nas identidades dos que nela trabalham.

Tal fenômeno tem sido discutido por pesquisadores por diferentes prismas, alguns o discutem a partir da mercantilização, da teoria institucional, outros o abordam a partir da perspectiva de Solé a respeito da empresarização ${ }^{5}$ (RODRIGUES; SILVA; DELLAGNELO, 2014; RODRIGUES; SILVA, 2009). Apesar de diferentes prismas poderem ser utilizados para a interpretação do fenômeno anteriormente descrito, podemos observar o predomínio de algumas inquietações comuns, entre as quais destacamos: a absorção de características mercadológicas pelo setor cultural, e as consequências dessa absorção por um setor com lógica de existência tão distinta.

Nas sociedades centradas no mercado, comumente, os desejos ou necessidades do patrocinador e do público, têm predominado sobre os desejos ou necessidades do povo, das organizações culturais, e dos artistas (BRANT, 2009), circunstância, que pode contribuir para a compreensão da arte como meio de produção e objeto de consumo. De acordo com Brant (2009), ao se vislumbrar a arte como meio de produção e objeto de consumo, corremos o risco de perdermos a sua condição única e insubstituível, para considerá-la como mera reprodutora de um sistema incapacitante. Artistas de todos os tempos e de todas as culturas de algum modo vivenciaram a tensão entre a arte e o mercado. Entretanto, a exploração financeira encontrada nas artes do século XX não possui precedentes.

Frente tal contexto, observamos que a atividade artística, seja ela qual for - música, literatura, teatro, dança, pintura -, apresenta uma dupla face, "o lado encantador do aprofundamento e da realização de si mesmo, mas também o lado sombrio da concorrência, das diferenças espetaculares do sucesso, bem como das desigualdades que produzem essas diferenças" (MENGER, 2005, p. 8). Quando se trata de relações de emprego, o artista

\footnotetext{
${ }^{5}$ Para Solé (2008 apud RODRIGUES; SILVA; DELLAGNELO, 2014), a empresa converteu-se em um modelo para os indivíduos e organizações. Nessa perspectiva, o mundo é organizado para e pela empresa. Yves-Marie Abraham (2006), que junto de Solé é um importante autor para compreensão desta perspectiva, aponta como principais traços da concepção de empresa: "invenção e autonomização da realidade econômica"; "o mito fundador da escassez"; "a racionalidade moderna"; "a propriedade privada"; e, "a inovação e mito do progresso".
} 
enfrenta a dispersão de equipes abertas, trabalhando mediante trabalhos temporários, ou práticas de subcontratação (THROSBY, 2001; MENGER, 2005). Daqui resulta-se um triplo motivo de relevância do estudo do trabalho artístico: pelo seu conteúdo, pela exigência de dedicação individual no trabalho e pela forma de organização contratual do trabalho (MENGER, 2005).

Diante de tais fatos, novos horizontes de pesquisas envolvendo processos de subjetivação no trabalho surgem. As investigações a respeito das discussões envolvendo trabalho de criação acabam por possibilitar uma ampliação dos referenciais teórico-práticos (FERREIRA, 2011b). Assim, o trabalho artístico, essencialmente marcado pela flexibilidade, e por incertezas (MENGER, 2005; BENHAMOU, 2007), pode ser vislumbrado como um campo de estudos privilegiado para a investigação das vivências de prazer e sofrimento no trabalho, oferecendo contribuições para os aportes teóricos da psicodinâmica do trabalho. As investigações com referencial teórico da psicodinâmica sobre o fazer artístico podem ser consideradas recentes (ALVARENGA, 2013; ASSIS, 2008; SANTOS, 2008; SEGNINI, 2010; SEGNINI; LANCMAN, 2011; BUENO, 2012; FERREIRA, 2011a, 2011b; PIRES, 2011; LIMA, 2009).Tais investigações acabam por estender o campo de estudos "às formas de trabalho com forte engajamento subjetivo e alto grau de incerteza, voltadas à criatividade $\mathrm{e}$ caracterizadas por vínculos cada vez mais remotos com a organização do trabalho ${ }^{6 "}$ (FERREIRA, 2011b, p. 39).

\section{PSICODINÂMICA DO TRABALHO}

A psicodinâmica do trabalho enquanto abordagem teórico-metodológica de pesquisa e ação pode ser considerada recente e em construção, com rápida evolução nos últimos vinte anos (DEJOURS, 2012a). Durante sua evolução, variadas foram as mudanças ocorridas no mundo do trabalho, influenciadas pelo ambiente altamente turbulento, segundo o qual, reinventar as empresas, flexibilizar e alcançar um retorno de curto prazo tornou-se regra (PAES DE PAULA, 2002). A criatividade e a inventividade passaram a ser ainda mais valorizadas, e o trabalho de criação ganhou maior pertinência (MENGER, 2005).

A psicodinâmica do trabalho foi desenvolvida inicialmente por intermédio dos referenciais teóricos de um campo de investigação da década de 1980, denominado de psicopatologia do trabalho, cujo principal expoente é o francês Christophe Dejours

\footnotetext{
${ }^{6}$ Em Dejours (2008b) encontramos referências a situações de trabalho menos marcadas pela organização do trabalho - como trabalho artístico e o trabalho do psicanalista - enquanto atividades ainda pouco pesquisadas.
} 
(DEJOURS et al., 2014; DEJOURS, 2012a). Porém, com o avanço das pesquisas e a incorporação de conceitos advindos primeiramente da Ergonomia, Psicanálise e da Psiquiatria; em seguida, da Sociologia (Sociologia da Ética e Sociologia da divisão sexual do trabalho) e da Antropologia; e posteriormente da Filosofia (fenomenologia de Michel Henry e Escola de Frankfurt), do Direito e, mais atualmente, da Economia, a abordagem desenvolvida por Dejours evoluiu para uma construção própria (DEJOURS, 2013).

A utilização do conceito de psicodinâmica do trabalho em substituição ao de psicopatologia do trabalho ocorreu devido à opção por privilegiar o estudo da normalidade, sobre o da patologia. Ou seja, a atenção voltada ao sofrimento passa a ser deslocada para as condições que possibilitam a normalidade, (DEJOURS et al., 2014; DEJOURS, 2012a), e a normalidade passa a ser "considerada um enigma", (DEJOURS, 2012a, p. 152). Para a psicodinâmica, nem a normalidade nem a saúde mental são inatas, pelo contrário, são o objetivo de uma luta que termina diante de uma derrota, ou da morte (DEJOURS, 2012a). Portanto, a normalidade não pressupõe ausência de sofrimento, pelo contrário, pressupõe uma luta contra a desestabilização psíquica (DEJOURS, 1999), de tal modo, importa à Psicodinâmica do Trabalho a compreensão de como os trabalhadores conseguem se manter em certo equilíbrio psíquico, mesmo quando submetidos a situações de trabalho adoecedoras (MERLO, 2002).

Nesse sentido, a saúde no trabalho é entendida como uma construção mediada pela dinâmica intersubjetiva do reconhecimento, que ao conferir julgamento de utilidade, de beleza ao trabalho, possibilita a construção da identidade do trabalhador, considerada central para a obtenção da saúde psíquica (DEJOURS, 2012). Como característica importante da psicodinâmica do trabalho, mantida durante sua evolução histórica e conceitual, temos o fato de que ela não visa os sujeitos isoladamente, mas sim ao seu coletivo (DEJOURS et al., 2014; DEJOURS, 2012a), de tal forma que, ao diagnosticar o sofrimento psíquico no trabalho, a psicodinâmica busca intervenções voltadas para a análise da organização do trabalho, a qual os sujeitos estejam submetidos (MERLO; MENDES 2009).

No que diz respeito às vivências de prazer-sofrimento, ressaltamos que para a psicodinâmica do trabalho, prazer e sofrimento são indissociáveis, o que significa que o trabalho pode tanto ser fonte de prazer quanto de sofrimento (MENDES; MULLER, 2013). O constructo prazer-sofrimento é estudado pela psicodinâmica como único e dialético (MENDES, 2007b), e definidos por Ferreira e Mendes (2001, p. 494) como "uma vivência subjetiva do próprio trabalhador, compartilhada coletivamente e influenciada pela atividade de trabalho". Assim, compreendemos que tanto o prazer quanto o sofrimento são resultados 
de uma combinação da história do sujeito e são também influenciados pela organização do trabalho.

Podemos considerar, como uma das mais significativas contribuições da psicodinâmica, a articulação entre as dimensões psíquicas - que envolve buscar prazer e evitar o sofrimento - e a dimensão coletiva do trabalhar (MENDES; MULLER, 2013). Destacamos, que para a psicodinâmica do trabalho, tanto o prazer quanto o sofrimento são colocados em termos do coletivo de trabalho. Ou seja, tanto a experiência prazerosa, quanto penosa vivida no contexto de trabalho, são consideradas coletivamente.

Com o intuito de compreendermos como ocorrem as vivências de prazer-sofrimento e o contexto de trabalho artístico na região da grande Florianópolis, tendo em vista o processo de mercantilização da cultura, estabelecemos como categorias analíticas aquelas referentes aos eixos da Análise Psicodinâmica do Trabalho de Mendes e Araújo (2012), a saber: organização do trabalho; mobilização subjetiva; sofrimento, defesas e patologias. Cabe mencionar que discorreremos sobre cada categoria analítica, a seguir.

Ao contrário de uma visão que compreende a organização do trabalho a partir de uma busca de controle de situações cotidianas, o olhar da psicodinâmica, extrapola aspectos físicos, alcança as relações interpessoais, a subjetividade, e a dinâmica intersubjetiva mobilizada pelo trabalho (MENDES, 2007). Para a psicodinâmica, a organização do trabalho diz respeito: à divisão de tarefas e dos homens (LHUILIER, 2013); normas e regras; exigências técnicas; tempos e ritmos; relações com os pares, chefias e clientes; riscos; responsabilidades; e estilos de gestão (MENDES; ARAÚJO, 2012).

A psicodinâmica do trabalho considera que a mobilização subjetiva emerge das exigências e constrangimentos da organização, e por isso demanda um investimento do corpo, afetivo e cognitivo (MENDES; DUARTE, 2013; MENDES, 2007). Destarte, a mobilização subjetiva é considerada como uma fonte de prazer no trabalho (MENDES, 2007), e é definida por Dejours (1997), como um meio para lidar com o sofrimento, diferenciado das estratégias de defesa, por não implicar na negação ou minimização do sofrimento, mas sim na sua ressignificação. Com o intuito de facilitar a compreensão da mobilização subjetiva, desenvolvemos um quadro com uma breve definição de cada um de seus elementos constituintes, de acordo com o arcabouço teórico da psicodinâmica do trabalho. 


\section{Quadro 1 - Elementos Constituintes da Mobilização Subjetiva}

\begin{tabular}{|c|c|}
\hline \multicolumn{2}{|c|}{ ELEMENTOS CONSTITUINTES DA MOBILIZAÇÃO SUBJETIVA } \\
\hline INTELIGÊNCIA PRÁTICA & $\begin{array}{l}\text { Inteligência do corpo ligada à ideia de astúcia, que utiliza } \\
\text { de sua capacidade inventiva para criar novos saber-fazer, } \\
\text { transgredindo o trabalho prescrito. Mobiliza-se a partir de } \\
\text { situações imprevistas (DEJOURS, 1997, 2012b). }\end{array}$ \\
\hline $\begin{array}{l}\text { ESPAÇO PÚBLICO DE } \\
\text { DISCUSSÃO }\end{array}$ & $\begin{array}{l}\text { Espaço à fala constituído pelos trabalhadores para auto } \\
\text { expressão, autenticidade, e relação de equidade entre } \\
\text { aquele que fala e aquele que escuta (MENDES, 2007). }\end{array}$ \\
\hline COOPERAÇÃO & $\begin{array}{l}\text { Mobilização da livre vontade de agir ou trabalhar junto, } \\
\text { com base na confiança e solidariedade. Pode ocorrer tanto } \\
\text { horizontalmente, quanto verticalmente (DEJOURS, 2012b; } \\
\text { MENDES, 2007). }\end{array}$ \\
\hline RECONHECIMENTO & $\begin{array}{l}\text { Retribuição de natureza simbólica - proferida por atores } \\
\text { engajados na organização do trabalho -, capaz de oferecer } \\
\text { uma gratificação ao sujeito em relação as suas } \\
\text { expectativas, face a realização de si mesmo (DEJOURS, } \\
\text { 2012b). Tal julgamento pode assumir duas formas: o } \\
\text { julgamento da beleza; e o julgamento da utilidade. O } \\
\text { julgamento de utilidade diz respeito à utilidade econômica, } \\
\text { técnica ou social do trabalho realizado pelo sujeito, e é } \\
\text { proferido, sobretudo, verticalmente por superiores } \\
\text { hierárquicos, e eventualmente, por clientes DEJOURS, } \\
\text { 2008b, 2012b). O julgamento da beleza diz respeito a } \\
\text { termos principalmente estéticos (DEJOURS, 2012b). Este } \\
\text { julgamento só pode ser proferido por aqueles que } \\
\text { conhecem a fundo o trabalho (DEJOURS, 2012b). }\end{array}$ \\
\hline
\end{tabular}

Fonte: elaborado pelas autoras.

Segundo Mendes (2007), os elementos constituintes da mobilização subjetiva são: inteligência prática, espaço público de discussão, deliberação, cooperação e reconhecimento. Destacamos que tais elementos alimentam o prazer tanto direto, quanto indiretamente. Logo, permitem de um lado a expansão e o engajamento da subjetividade - que significa ter o trabalho como um local de investimento pulsional, de ressonância simbólica e sublimação - e de outro, são constituintes da subversão do sofrimento em prazer.

Além desses elementos, a psicodinâmica do trabalho atribui ainda relevância ao sofrimento, às estratégias de sua minimização e às patologias (MENDES E ARAÚJO, 2012). Com o objetivo de sintetizar a discussão a respeito dessa categoria, há no quadro 2 , uma breve definição de cada elemento constituinte da categoria sofrimento, defesas e patologias no trabalho, de acordo com a psicodinâmica do trabalho. 


\section{Quadro 2 - Elementos Constituintes da Categoria Sofrimento, Defesas e Patologias no Trabalho}

\begin{tabular}{|c|l|}
\hline \multicolumn{2}{|c|}{ ELEMENTOS CONSTITUNTES DA CATEGORIA SOFRIMENTO, DEFESAS E } \\
PATOLOGIAS NO TRABALHO \\
\hline \multirow{2}{*}{ SOFRIMENTO CRIATIVO } & $\begin{array}{l}\text { No sofrimento criativo, há uma mobilização subjetiva por } \\
\text { parte do sujeito que possibilita a subversão do seu } \\
\text { sofrimento em prazer. No entanto, há necessidade haver } \\
\text { liberdade por parte da organização do trabalho. } \\
\text { (DEJOURS et al., 2014). }\end{array}$ \\
\hline SOFRIMENTO PATOGÊNICO & $\begin{array}{l}\text { O sofrimento patogênico é considerado relacionado à falta } \\
\text { de liberdade oferecida ao trabalhador e de flexibilidade da } \\
\text { organização do trabalho, o qual impede que o trabalhador } \\
\text { seja considerado sujeito do seu comportamento, sendo } \\
\text { necessária a utilização de estratégias de defesa para } \\
\text { suportar o contexto de trabalho (DEJOURS et al., 2014). }\end{array}$ \\
\hline ESTRATÉGIAS DE DEFESAS & $\begin{array}{l}\text { Recursos construídos pelos trabalhadores, de maneira } \\
\text { individual e coletiva, para minimizar a percepção do } \\
\text { sofrimento no trabalho (DEJOURS, 2012b; MENDES, } \\
\text { 2007). }\end{array}$ \\
\hline PATOLOGIAS NO TRABALHO & $\begin{array}{l}\text { Forma de adoecimento decorrente do contexto sócio } \\
\text { histórico e da organização de trabalho na qual se manifesta } \\
\text { e que afeta as relações sociais e de trabalho (FERREIRA, } \\
\text { 2013, p.275). }\end{array}$ \\
\hline
\end{tabular}

Fonte: elaborado pelas autoras.

Percebemos que os trabalhadores não permanecem passivos em relação aos constrangimentos impostos pela organização do trabalho. Pelo contrário, para lidar com o sofrimento, os trabalhadores desenvolvem estratégias defensivas (DEJOURS et al., 2014; DEJOURS, 2012b). No entanto, nem sempre as estratégias de enfrentamento do sofrimento conseguem ser efetivas na sua minimização e na recusa daquilo que faz sofrer, o que pode acarretar na manifestação de patologias físicas e mentais nos trabalhadores.

Ressaltamos que o sofrimento assume variados sentidos durante o processo de adoecimento. A dor que inicialmente pode ser sentida como banal, com o passar do tempo pode vir a limitar o movimento do corpo, forçando, dessa forma, o trabalhador a reconhecêla. Apesar de o trabalho ser constituinte da subjetividade do trabalhador, mediando a construção da sua identidade, por intermédio do reconhecimento; o trabalho pode também conferir ao trabalhador uma condição alienante, a qual necessita ser superada em nome da saúde mental do sujeito. Nesse sentido, acreditamos que a psicodinâmica do trabalho fornece aporte teórico para a investigação das vivências de prazer e sofrimento no trabalho artístico, e para a existência de análises que compreendam a dinâmica da esfera artística e que apontem suas contradições. 


\section{MÉTODO}

Em relação aos procedimentos metodológicos, salientamos que esta é uma pesquisa qualitativa de corte de tempo transversal. No que concerne à perspectiva epistemológica, a abordagem desta pesquisa seguiu pressupostos baseados na Psicodinâmica do Trabalho. Destarte, utilizamos da referida abordagem, enquanto metodologia - especialmente, no que condiz às categorias de análise - e arcabouço teórico. Do ponto de vista epistemológico, a psicodinâmica do trabalho é uma teoria de natureza crítica do trabalho (MENDES, 2007; MERLO E MENDES, 2009), que compreende dimensões da construção-reconstrução das relações existentes entre sujeitos-trabalhadores e a realidade concreta de trabalho. Tece críticas ao trabalho prescrito, desestabiliza o que já está posto, e acaba por traduzir o trabalho a partir dos processos de subjetivação e vice-versa (MENDES, 2007). Tais especificidades, exigem uma qualificação teórico-metodológica, que seja capaz de articular a teoria social e do sujeito, a uma condução centrada na escuta do outro. (MENDES; ARAÚJO, 2012).

Fizeram parte deste estudo, quatro artistas atuantes na região da grande Florianópolis. Para preservar a identidade dos participantes, seus nomes foram substituídos, neste estudo, por: Luiz, Equilibrista, Fernando e Ricardo. Haja vista a complexidade concernente à organização e a definição dos setores denominados criativos e culturais, David Throsby (2001b) elaborou um modelo que categoriza as atividades relacionadas a tais setores em três círculos concêntricos. No núcleo do modelo encontram-se as artes criativas tradicionalmente conhecidas como: artes visuais; literatura; patrimônio cultural; música; dança; artesanato; artes performáticas; e práticas que envolvem o uso de tecnologia (arte multimídia). Para FGV (2015), a economia da cultura corresponde a setores tipicamente conectados à produção artístico-cultural, a saber: música; dança; teatro; artes visuais; literatura; patrimônio cultural e circo. Assim, um primeiro pressuposto para a seleção dos artistas contemplados por este estudo foi que eles atuassem em áreas do setor cultural as quais estivessem em consonância com as áreas abrangidas pela delimitação de economia da cultura, realizadas pela Fundação Getúlio Vargas (2015), e com núcleo do modelo composto de três círculos concêntricos, proposto por Throsby (2001).

Outro pressuposto para a seleção dos artistas abrangidos por este estudo foi o delineamento de um grupo de artistas a partir da satisfação de alguns aspectos. Para Throsby (2001), o delineamento de um grupo de artistas profissionais deve depender da aplicação de um conjunto de critérios que podem exigir que o indivíduo satisfaça pelo menos dois dos 
seguintes pressupostos: Demonstrar evidência de aceitação pelos pares; Possuir qualificações educacionais adequadas e/ou ter um conjunto suficiente de experiência em atividades artísticas ao invés de treinamento formal; Dedicar uma quantidade mínima de tempo no trabalho criativo durante um período determinado; Pertencer a um organismo de certificação; e Ganhar certo nível de rendimentos advindo do trabalho artístico. Desse modo, a delimitação dos artistas abrangidos por este estudo devia satisfazer pelo menos dois dos pressupostos sugeridos por Throsby (2001).

Como instrumentos e procedimentos de coletas de dados, utilizamos entrevistas semiestruturadas individuais em profundidade, com duração aproximada de uma hora cada, e realizamos observação do processo de trabalho. Enfatizamos que Mendes (2007) refere que algumas variações na coleta de dados em Psicodinâmica do Trabalho podem ser realizadas e sugere, entre outras técnicas, o uso de entrevistas semiestruturadas individuais. Nessa perspectiva, acreditamos que as entrevistas individuais, realizadas com diferentes sujeitos, quando analisadas em conjunto, mantenham os princípios centrais da psicodinâmica, ou seja, podem "ser capazes de revelar o trabalho na sua complexidade, desvelando mediações, contradições e intersubjetividade" (MENDES, 2007, p. 67).

Com o intuito de considerar a escuta e a fala do sujeito como prioridade, favorecendo assim a livre expressão dos participantes, elaboramos um roteiro de entrevista formado por questões baseadas em três categorias de análise: organização do trabalho; mobilização subjetiva; sofrimento, defesas e patologias. Conforme anteriormente explicitado, tais categorias foram previamente estabelecidas com base nos eixos da Análise Psicodinâmica do Trabalho (APDT) de Mendes e Araújo (2012) ${ }^{7}$.

Segundo Mendes e Araújo (2012), os eixos da APDT podem variar, bem como seus respectivos temas, de acordo com os casos estudados. Todavia, devido à coerência com a pesquisa aqui desenvolvida, nos apoiamos nas autoras, as quais propõem três eixos com os seguintes temas: Eixo I - Organização do Trabalho - divisão de tarefas, normas e regras; exigências técnicas, tempos e ritmos, relações sócio profissionais, estilos de gestão, responsabilidade, e riscos; Eixo II - Mobilização Subjetiva - Inteligência Prática, Espaço de Discussão, Cooperação, Reconhecimento, e Sofrimento Criativo; Eixo III - Sofrimento, Defesas e Patologias - Sofrimento Patogênico, Defesas, e Patologias. A única adaptação

\footnotetext{
7 Mendes e Araújo (2012) desenvolveram uma técnica denominada de Análise Clínica do Trabalho (ACT), para organizar os conteúdos das falas dos entrevistados, com base na qualidade e no significado do discurso. A Análise da Psicodinâmica do trabalho (APDT) é uma etapa da ACT correspondente a estruturação dos eixos de análise, fomentada pela transcrição das sessões ou registro das falas.
} 
realizada nos temas correspondentes aos eixos de análise ocorreu nas temáticas referentes à mobilização subjetiva, pois optamos em tratar tal temática, apenas nos seus elementos constitutivos. Desse modo, o sofrimento criativo, foi tratado junto do eixo III.

Salientamos que as questões elaboradas não foram associadas a um roteiro a ser estritamente seguido, pelo contrário, tais questões indicaram uma sugestão de trajetória para que fosse possibilitado ao pesquisador explorar os temas da pesquisa. No que concerne à observação do processo de trabalho, cumpre destacar que a mesma foi realizada conforme a disponibilidade de cada artista e registrada por meio da escrita de situações observadas e de fotografias incluídas no diário de campo da pesquisa. Já o conteúdo das entrevistas, foi analisado com base no método de análise de conteúdo categorial desenvolvido por Bardin (2016), partindo de categorias de análise previamente definidas: organização do trabalho; mobilização subjetiva; e sofrimento, defesas e patologias. No que tange ao agrupamento do conteúdo verbal das entrevistas, é válido elucidar, que buscamos analisar os dados em sua totalidade, sem que se priorizasse, de modo exclusivo, àqueles com maior frequência, seguindo assim, uma abordagem qualitativa de pesquisa.

\section{O TRABALHO ARTÍSTICO EM ANÁLISE}

A seguir, os dados serão organizados e analisados com base nas categorias de análise que compõem esta investigação. Nesse sentido buscaremos apresentar singularidades e semelhanças entre estes casos . Para tal feito, realizaremos inicialmente, uma breve descrição de cada artista.

Luiz, natural de Florianópolis, Santa Catarina, à época da pesquisa tinha 31 anos de idade, era ator de teatro, produtor cultural, e professor auxiliar de iniciação cênica e montagem teatral. Graduado em publicidade e propaganda, pós-graduado em marketing estratégico, Luiz residia com seus pais e trabalhava exclusivamente como artista há 5 anos. Equilibrista, natural de Florianópolis, Santa Catarina, tinha 25 anos, era coreógrafa, bailarina, e professora de dança. Com graduação em arquitetura em andamento, ela residia com seus pais, possuía aproximadamente 20 anos de participações em festivais e outros eventos de dança, e trabalhava exclusivamente como artista há 4 anos.

Fernando, natural de Porto Alegre, Rio Grande do Sul, tinha 29 anos, era músico e luthier. Com formação superior de tecnologia em mecânica industrial, Fernando era casado e residia com sua esposa. À época da pesquisa, Fernando estava há 10 anos trabalhando exclusivamente como artista. Ricardo, natural de Laguna, Santa Catarina, possuía 49 anos, 
denominava-se um artista múltiplo, atuando nas artes visuais, teatro e música. $\mathrm{O}$ artista possuía o ensino médio completo, era casado e residia com sua esposa e filho. Destacamos que Ricardo, assim como os demais participantes, trabalhava exclusivamente como artista e possuía aproximadamente 30 anos de experiência com o trabalho artístico.

\subsection{ORGANIZAÇÃO DO TRABALHO}

Neste tópico, damos início à Análise Psicodinâmica do Trabalho com foco na organização do trabalho. Neste sentido, aqui buscamos observar elementos relativos: à divisão de tarefas e dos homens (LHUILIER, 2013); normas e regras; exigências técnicas; tempos e ritmos; relações com os pares, chefias e clientes; riscos; responsabilidades; e estilos de gestão (MENDES; ARAÚJO, 2012).

Diante da necessidade de retorno financeiro e do desejo de dedicar-se exclusivamente à arte, pareceu ser comum aos artistas, a facilidade de adaptação às oportunidades de trabalho que surgem, mesmo que essa situação, os conduza a atuar em áreas distintas daquelas de sua preferência, condição observada, principalmente, em Fernando e Ricardo. Nas palavras de Ricardo: "Sabe aquela pergunta que tu fizesses para mim, sobre porque eu era um artista múltiplo? Justamente por isso. Quando o mercado está ruim de um lado eu vou migrando, eu vou me adaptando”. Dessa maneira, ressaltamos também a fala de Fernando: “(...) eu penso, eu prefiro tocar pagode, por exemplo, ou cumprir uma jornada de trabalho em outra cidade e ter que seguir ali um padrão de trabalho? Então vamos tocar, pelo menos eu vou estar no meu meio".

Além da adaptação às oportunidades de trabalho, observamos que frente à necessidade de retorno financeiro e ao desejo de dedicar-se exclusivamente à arte, os artistas também tendem a se adaptar às condições de trabalho que lhes são oferecidas, sem demonstrar um comportamento resistente na tentativa de modificar tais situações, assim como descrito por Transform (2008) e Loacker (2013). Desse modo, enfatizamos que nenhum dos artistas participantes deste estudo, possui vínculo formal de trabalho, o que implica na ausência de benefícios trabalhistas assegurados pela CLT. De modo oposto a Luiz e Equilibrista, Fernando e Ricardo, por efetuarem contribuição previdenciária enquanto autônomos, possuem alguns benefícios trabalhistas, como: auxílio doença e aposentaria.

Salientamos que as circunstâncias anteriormente apresentadas não são consideradas exclusivas da região aqui estudada. Autores de diferentes países, como Menger (2005), Benhamou (2007), Transform (2008), Banks, Gill e Taylor (2013) e Loacker (2013), referem 
que, via de regra, o trabalho artístico apresenta-se como uma forma de emprego precarizado, com trabalhos temporários - incluindo-se projetos ou contratos de trabalho com vários clientes ao mesmo tempo -, e com a presença de poucos benefícios trabalhistas.

Com base no estudo apresentado pela FGV (2015), observamos que o setor cultural apresenta uma média de trabalhadores formais relativamente menor que a média de todos os setores econômicos do país. Neste estudo afirmamos ainda, que apesar de haver no setor cultural uma média de trabalhadores sem carteira assinada relativamente maior que aos demais setores econômicos, os trabalhares da cultura tendem a possuir um grau de qualificação superior aos demais trabalhadores brasileiros. No tocante ao contexto de trabalho artístico da grande Florianópolis, os protagonistas deste estudo, referiram que percebem que existem artistas trabalhando, apresentações ocorrendo, no entanto, para eles, parece que a região não comporta a produção cultural existente. Conforme Ricardo, por exemplo, o incentivo público à arte em seu município de residência é limitado, tanto relacionado a políticas públicas quanto à existência de equipamentos culturais.

Diante do exposto, salientamos que de acordo com o suplemento de Cultura do Perfil dos Estados e Municípios Brasileiros (IBGE, 2015), e o Anuário de Estatísticas Culturais (MinC, 2010), podemos observar a presença marcante de grupos artísticos, tanto na referida região quanto no estado de Santa Catarina. Contudo, de acordo com o Centro Técnico de Artes Cênicas, apenas dois dos municípios da região possuem teatros - Florianópolis e São José (CTAC, 2017). Fato este, que pode ser reflexo da descontinuidade de ações e das políticas culturais praticadas no estado. Não obstante, ressaltamos que tal descontinuidade não deve ser considerada presente apenas em Santa Catarina. Nesse sentido, retomamos o argumento de Rubim (2007), onde o autor refere que tristes tradições marcam a história das políticas culturais brasileiras: ausências, autoritarismos e instabilidades. De acordo com Rubim (2015), estas tristes tradições permeiam tanto a trajetória, quanto a situação atual das políticas culturais no Brasil.

Outra circunstância associada ao trabalho artístico, trazida à luz pelos participantes desta pesquisa foi a variabilidade de renda que permeia suas carreiras. Diante da repetida alternância de trabalhos, ocasionada pela presença de contratos temporários sem vínculo formal de trabalho e/ou entre encomendas por obras, músicas ou espetáculos, os artistas enfrentam uma grande variabilidade de renda. Tal variabilidade, em conjunto com os fatos anteriormente apresentados, tende a influenciar os artistas a lançarem-se em atividades e/ou projetos com mais de um cliente ao mesmo tempo. Assim, nem sempre os artistas conseguem estabelecer uma rotina com local e horário de trabalho fixo. Observamos que em períodos 
próximos a eventos festivos ou a apresentações, em que há uma maior intensidade de trabalho, há também uma maior tendência à existência de sobrecarga física e psicológica. Destacamos uma situação em que estivemos presentes em um evento de dança, em um domingo, cujo horário de chegada ao evento estava programado para as 8horas, o início das apresentações para as 19horas e a última apresentação de Equilibrista encerrou as 00horas30min do dia seguinte.

A ausência de horários de trabalho fixos e a realização de atividades e/ou projetos com mais de um cliente ao mesmo tempo tornam cada vez mais porosas as fronteiras entre vida pessoal e trabalho. Nas palavras de Fernando: "Na verdade o trabalho está comigo, né?! Onde eu vou ele vai comigo". Para Fernando, profissionais que conseguem estabelecer uma fronteira mais definida entre vida pessoal e trabalho dispõem de um "privilégio" que os músicos, e a maior parte dos artistas, não possuem. Nessa acepção, vale recuperar a afirmação de Transform (2008), segundo o qual, em uma atividade profissional em que barreiras entre vida pessoal e profissional praticamente inexistem, ou conforme diria Gaulejac (2014) em que tais barreiras se tornam cada vez mais porosas, a precarização de um determinado contexto de trabalho, pode implicar na precarização da vida do sujeito.

Um fator a ser destacado é a existência de um bom relacionamento interpessoal, entre membros de um mesmo grupo ou banda. Entretanto, ressaltamos que a despeito de geralmente haver um bom relacionamento interpessoal entre artistas que integram um mesmo grupo ou banda, observamos um caráter conflituoso na relação entre artistas de grupos ou bandas diferentes. Dessa maneira, podemos entender que há na esfera artística, uma tendência à manutenção de laços de cooperação de membros de um mesmo grupo, mas que a busca por espaços, entre diferentes grupos de artistas, tende a apresentar um comportamento individualista.

Outra situação apontada pelos participantes desta pesquisa como característica do trabalho artístico é a forte cobrança por desempenho e resultados. Apesar de haver em alguns momentos, uma forte cobrança por desempenho e qualidade das obras criadas, proveniente do contratante e do público, observamos que a principal fonte de cobranças por resultados e desempenhos dos artistas tende a ser individual. Destacamos que todos os artistas afirmaram que há em seu trabalho forte cobrança em termos de desempenho, no entanto, notamos que aqueles com maior tempo de trabalho no campo artístico, Fernando e Ricardo, efetuam uma cobrança pessoal mais voltada às suas performances, enquanto Luiz e Equilibrista, cobram-se também por resultado financeiro. Destarte, pressupomos que a cobrança pessoal do artista por 
resultado financeiro possa estar associada à consolidação, ou não, de seu nome no meio artístico e a conquista da estabilidade financeira.

A vivência de situações imprevistas também é mencionada como algo constante no cotidiano dos artistas, o que aponta para uma necessidade frequente de inventividade. Assim como os demais artistas, Luiz relata, que enquanto ator de teatro, seu trabalho é marcado pela presença de circunstâncias imprevistas e que necessitam de ação rápida, pois "o show não pode parar." O trabalho dos artistas é norteado por um saber prático, construído a partir de trocas com os pares e com o tempo de trabalho, visto que, diante de situações complexas, variadas e imprevistas, nem sempre as prescrições e o conhecimento-técnico científico são suficientes. Nesse momento, emerge o que Christophe Dejours (data) denomina de trabalho real.

No que diz respeito ao estilo de gestão, observamos nas rotinas de trabalho, a existência de algumas particularidades que podem estar relacionadas à área de atuação de cada um deles. Equilibrista, a qual trabalha em uma escola de dança, apresenta marcas de uma lógica de gestão taylorista/fordista, intimamente conectada com a gestão burocrática, especialmente, no que diz respeito à execução de tarefas repetitivas, separação entre trabalho de concepção e execução. Todavia, salientamos que existem diferenças fundamentais à lógica taylorista/fordista, relacionadas ao uso da criatividade e a uma flexibilização das relações de trabalho e vínculos trabalhistas, que podem ser consideradas próprias do atual sistema econômico e de um estilo de gestão associado à burocracia flexível, conforme proposto por Paes de Paula (2002).

No que concerne ao trabalho de Luiz, percebemos a existência de um estilo de gestão que se difere da gestão burocrática, principalmente quando se observa a dinâmica horizontalizada de trabalho no centro cultural e no grupo de teatro. Os casos de Fernando e Ricardo apresentam em inúmeros momentos a ocorrência de tarefas repetitivas e de divisão entre trabalho de concepção e execução. Contudo, são essencialmente marcados pela existência de vínculos empregatícios (formais/informais) remotos com organizações, assim como descrito por Dejours (2008b) e Ferreira (2011b), tendo em vista a predominância de trabalhos desenvolvidos na forma de prestação de serviços. Posto isto, consideramos que assim, como ocorre em outras áreas profissionais, diante da aproximação com lógica mercadológica, os artistas acabam por experienciar a flexibilização das relações de trabalho e de vínculos trabalhistas, bem como de uma liberdade e autonomia na execução do trabalho limitadas. 


\subsection{MOBILIZAÇÃO SUBJETIVA}

Daremos aqui, continuidade à Análise Psicodinâmica do Trabalho, agora com foco nos elementos constituintes da mobilização subjetiva: Inteligência prática; Espaço público de discussão; Cooperação; e Reconhecimento. Em seguida, identificaremos as circunstâncias relacionadas às vivências de prazer no trabalho artístico.

Os estudos em psicodinâmica pressupõem que homens e mulheres experimentam o real do trabalho quando ultrapassam as prescrições, no sentido de superar os limites da organização do trabalho e lidar com imprevistos (VASCONCELOS, 2013; MENDES; ARAÚJO, 2012; DEJOURS, 2012a, 2012b). Como forma de ajustamento criativo à prescrição do trabalho, mobiliza-se uma forma de inteligência, denominada de inteligência prática, que envolve afetividade e cognição ao transgredir a organização (VASCONCELOS, 2013).

A inteligência prática se faz presente na fala de Ricardo, ao conhecermos uma de suas esculturas expostas em uma praça pública, na medida em que o potencial criador do artista incorpora a astúcia, engenhosidade e inventividade no desenvolvimento de situações que subvertem a prescrição para dar conta do real, ou da situação imprevista que se fez presente. A escultura era composta por partes distintas (dois pescadores, dois peixes e um barco) e antes que o artista finalizasse sua montagem, pessoas subiram na peça referente ao barco, o que fez que a escultura apresentasse fissuras. Ao perceber tal situação, Ricardo fez uma laje de concreto na parte superior do barco, para evitar que alguém se machucasse.

A compreensão de que o trabalho artístico é marcado pela presença de situações imprevistas é unânime entre os sujeitos desta pesquisa, bem como o entendimento de que para lidar com essas situações, de maneira a evitar ou diminuir a percepção de algo diferente do planejado e/ou de erros, por parte do público exige técnica, experiência e amadurecimento profissional. Nas palavras de Equilibrista: "Em eventos mais formais, que têm coreografia pronta, acontece às vezes de dar um branco, de esquecer a coreografia. (...) saber lidar (...) é questão de amadurecimento. Quanto mais tu vais passando, mais tu vais aprendendo."

Além do uso da inteligência prática, percebemos a existência de um espaço público de discussão e de relações de cooperação no cotidiano dos protagonistas desta investigação. No entanto, destacamos que a existência e manutenção de um espaço público de discussão, bem como das relações de cooperação no trabalho desses artistas, ocorrem de maneira variada. Notamos que, apesar de existir em alguns momentos, um espaço para discussões pertinentes à maneira de executar as atividades de trabalho, não foi possível constatar a existência de um 
espaço onde o artista, enquanto trabalhador, possa repensar seu trabalho ao falar sobre ele, interpretá-lo e modificá-lo na busca da ressignificação de situações sofríveis.

Inferimos que a presença de algumas circunstâncias, podem dificultar a existência e manutenção de um espaço público de discussão, enquanto um espaço de organização política e das relações de cooperação, a saber: trabalhos temporários, realização de atividades e/ou projetos com mais de um cliente ao mesmo tempo e existência de uma convivência conflituosa entre artistas de grupos ou bandas diferentes. Enquanto profissionais das artes, os sujeitos desta pesquisa, acreditam que a existência de uma certa tensão proveniente do ambiente de competições, busca por espaço e destaque em eventos, dificulta a organização dos artistas para debaterem questões pertinentes ao trabalho e ao contexto de trabalho em que estão inseridos e esta circunstância, segundo eles, tende a apresentar reflexos negativos na busca por mudanças e melhorias das condições de trabalho a que estão submetidos.

No que concerne às relações de cooperação, não foi possível perceber a sua existência em todos os trabalhos desempenhados pelos artistas entrevistados, exceto no caso de Luiz, uma vez que o artista de teatro e seus colegas tentam manter, tanto no centro cultural quanto no grupo de teatro, práticas organizacionais associadas a um estilo de gestão mais horizontalizado. A despeito de não ser possível depreender a existência de relações de cooperação em todos os trabalhos desempenhados pelos protagonistas deste estudo, pudemos realizar uma reflexão sobre o julgamento da beleza, para compreender o modo como se dão as relações de cooperação e a mobilização subjetiva, implicados no trabalho coletivo dos artistas em questão (SEGNINI, 2010).

Apesar de se perceber que o julgamento da beleza de um trabalho tende a auxiliar na existência e manutenção de relações de cooperação entre os pares, bem como na mobilização subjetiva do coletivo de trabalho, observamos que a tensão decorrente do ambiente de competições, busca por espaço e destaque em eventos também dificulta o reconhecimento da beleza do trabalho do outro artista e/ou grupo. Tal situação tende a dificultar a existência de relações de cooperação, a manutenção de um espaço de discussão, bem como a legitimação de ações referentes ao uso da inteligência prática entre artistas de diferentes grupos.

As vivências de prazer no trabalho artístico, por sua vez, foram relacionadas: ao reconhecimento pelo trabalho desenvolvido; ao fato de exercer a profissão de livre escolha; ao processo de criação envolvido na atividade artística; à liberdade para criar; às experiências exitosas diante de circunstâncias imprevistas. No tocante ao reconhecimento pelo trabalho desenvolvido enquanto possibilidade de vivenciar prazer no trabalho artístico, verificamos que, dependendo de sua origem, pode haver um maior destaque ao julgamento recebido e 
uma maior vivência de prazer. Para os artistas participantes deste estudo, há uma perspectiva de vivenciar prazer quando o público reconhece o trabalho desenvolvido, bem como a atividade artística como uma atividade de trabalho. No entanto, observamos uma maior vivência de prazer quando o reconhecimento e o julgamento do trabalho desenvolvido é advindo dos pares. Acreditamos que a circunstância anteriormente descrita, reitere a importância concedida ao reconhecimento enquanto retribuição simbólica na construção da identidade do trabalhador e para a busca de equilíbrio psíquico. (DEJOURS, 2012b).

Assim como o reconhecimento do trabalho desenvolvido, percebemos que o fato de exercer a profissão de livre escolha, é considerado pelos artistas como uma possibilidade de vivenciar prazer em seu trabalho. Destacamos uma fala de Fernando: “(...) trabalhar com arte (...) meio que mexe com o bem-estar, a alma. (...) sinto prazer porque estou na minha área.

De acordo com Freud ([1930]2011), quando a atividade profissional é àquela de livre escolha do sujeito, por meio da sublimação, ela pode se constituir como uma fonte de satisfação. A atividade artística, quando livremente escolhida, trata-se de uma das principais atividades de trabalho, que por meio da sublimação, pode constituir-se como uma via de satisfação. Nesse sentido, constatamos que em todos os casos aqui estudados, a atividade artística, foi livremente escolhida enquanto trabalho, e que por meio da sublimação, se constitui como uma via de satisfação.

O processo de criação e a liberdade para criar são apontados pelos sujeitos deste estudo como possibilidades de vivenciar prazer em seu trabalho. Entretanto, ressaltamos que a necessidade de retorno financeiro, bem como o desejo de dedicar-se exclusivamente à arte, pode impulsionar os artistas a se adaptarem às oportunidades e condições de trabalho que lhes são impostas, situação que tende a limitar a liberdade do artista ao criar.

Outra circunstância apontada pelos artistas participantes deste estudo, como possibilidade de vivenciar prazer em seus trabalhos, trata-se da existência de experiências exitosas diante de situações imprevistas. Ao relatarem que situações imprevistas são frequentes no cotidiano do artista, os protagonistas deste estudo elucidam que conseguir contornar a situação, de modo a minimizar ou evitar a percepção de algo diferente do esperado e/ou de erros, quer seja por parte do contratante, cliente, e/ou público, é algo que exige experiência e habilidade no que se faz. Assim, acreditam que possuir experiências exitosas frente às situações imprevistas são possibilidades importantes de vivenciar prazer em seu trabalho. Segundo Equilibrista, por exemplo: "Passar por aquele momento de enfrentar o público e improvisar, de dar branco e de ter que se virar na hora, é um prazer muito grande". 


\subsection{SOFRIMENTO, DEFESAS E PATOLOGIAS}

Os quatro protagonistas deste estudo afirmaram que parece haver uma tendência à não compreensão do fazer artístico enquanto trabalho, por parte de sujeitos que não pertencentes à esfera artística, fato que é apontado por eles como uma das vivências de sofrimento em seu trabalho. Conforme Ricardo: "De vez em quando alguém me pergunta: Tu não fazes nada além de arte? (...) Não tens carteira assinada?” Equilibrista relata que parece existir uma dificuldade na compreensão da atividade artística enquanto trabalho, por ser uma ocupação profissional relacionada ao prazer. Nas suas palavras: “(...) o nosso trabalho, não é visto como algo que tenha valor por ser algo prazeroso, e é um trabalho tanto quanto é outro trabalho".

A partir de tais falas, acreditamos que a palavra trabalho ainda tende a ser associada a algo penoso. Como diria Freud ([1930]2011), nem todos conseguem observar o potencial sublimatório que uma atividade profissional possui, circunstância, que dificulta a percepção do trabalho como uma via de satisfação. Assim, quando se observa a atividade artística como uma atividade profissional com alto potencial sublimatório e que se constitui como uma possibilidade clara de vivenciar prazer, parece haver uma tendência à negação de que tal atividade possa ser considerada como um trabalho.

Nesse sentido, acreditamos que a ausência de vínculos formais de trabalho, inexistência ou pouca presença de benefícios trabalhistas assegurados pela CLT e a instabilidade financeira que permeiam a carreira do artista, também podem contribuir para a não compreensão do fazer artístico como um trabalho por sujeitos não pertencentes à esfera artística, e para a vivência de sofrimento no trabalho por parte dos entrevistados.

Não compreender a atividade artística enquanto trabalho é não reconhecer o artista enquanto trabalhador, e tal relação não permanece neutra no que concerne à saúde mental de tais profissionais, pelo contrário, pode causar desestabilização psíquica. Salientamos que a presença de reconhecimento pode ser tanto uma possibilidade de vivenciar prazer no trabalho, proporcionando autorrealização ao trabalhador e auxiliando na construção de sua identidade, quanto a sua ausência, pode implicar na não subversão do sofrimento em prazer, viabilizando o surgimento de uma crise de identidade ou de outras patologias.

Em tal contexto, o reconhecimento no trabalho artístico não deve ser associado, exclusivamente, à compreensão ou não de sua atividade enquanto trabalho - situação aqui entendida, como utilidade social atribuída ao trabalho artístico -, mas também à utilidade e beleza da obra criada. Como mencionamos anteriormente, os protagonistas deste estudo, 
relacionam a ausência de reconhecimento às possibilidades de vivenciar sofrimento em seu trabalho. Percebemos que, mesmo quando não exposto de maneira clara, o desejo de reconhecimento de um trabalho desenvolvido se faz presente no cotidiano de tais artistas.

Nos casos estudados, foi possível a percepção da existência de reconhecimento entre os artistas e seus pares, por meio do julgamento da beleza de um trabalho. No entanto, observamos também, que a tensão decorrente do ambiente de competições, a busca por espaço e destaque em eventos, dificultam o reconhecimento da beleza do trabalho do outro artista e/ou grupo, e podem ser relacionadas à possibilidade de vivenciar sofrimento no trabalho artístico. Apesar de referirem que o não reconhecimento proveniente do público é relacionado ao sofrimento em seu trabalho, para os sujeitos deste estudo, há uma maior vivência de sofrimento, quando não há reconhecimento advindo da avaliação dos outros artistas.

Outro fato apontado como possibilidade de vivenciar sofrimento no trabalho artístico é o ritmo de trabalho intenso. Frente a um contexto de trabalho que envolve situações como a ausência e/ou pouca presença de vínculos formais de trabalho, de benefícios trabalhistas e inseguranças financeiras, frequentemente, os artistas desenvolvem projetos ou atividades com mais de um cliente ao mesmo tempo. Dessa maneira, em inúmeros momentos, tais artistas acabam intensificando seu ritmo de trabalho, fato que, principalmente, em datas próximas a eventos festivos, bem como a apresentações e/ou participações em eventos, lhes causam desgaste físico e psíquico.

Assim como o ritmo de trabalho intenso, a limitação da liberdade de criação é outro aspecto apontado como fonte de sofrimento no trabalho artístico. Para Ricardo, a relação comercial proveniente da necessidade de adequação de suas obras ao desejo do contratante e/ou cliente limitam a possibilidade de criar livremente. Tal qual Ricardo, Fernando elucida que devido à necessidade de retorno financeiro e o desejo de dedicar-se exclusivamente à música, o artista foi impulsionado a adaptar-se às oportunidades de trabalho que surgiam.

Segundo Fernando, muitas vezes os artistas se submetem a trabalhos que podam a sua criatividade ou a condições de trabalho precárias, porque precisam sobreviver. De acordo com ele, somente alguém com "um nome forte", consegue ter uma atitude de maior resistência às condições anteriormente descritas, negando trabalhos que lhes exijam tal feito. Fernando afirma ainda, que inúmeras vezes os músicos, principalmente aqueles que não possuem grande renome, ao criar uma composição musical, são constrangidos pelo contratante a seguir uma determinada estrutura padrão de composição musical. Ressaltamos que tal estrutura é estabelecida com base em músicas de grande assimilação pelo público. 
Diante do exposto, se faz necessário retomar ao argumento de Dejours (1999), quando o autor afirma que o artista não pode escapar das relações de mercado. Ao se estabelecer relações mercantis entre o artista, o público e/ou o patrocinador, corremos o risco de a arte ser percebida como um meio de produção e a criação artística como um objeto de consumo, possibilitando que os desejos ou necessidades do patrocinador e do público, predominem sobre os desejos ou necessidades dos artistas. Destarte, pode ocorrer a instalação do sofrimento, pois não se vê mais na arte, uma atividade destinada a harmonizar, em primeiro lugar, os desejos não gratificados do artista, e em segundo lugar, os desejos do público.

Frente à vivência de sofrimento, há que se destacar o papel das defesas que entram em ação para possibilitar ao ego o estabelecimento de soluções, buscando que alguns componentes de conteúdos mentais não desejados, cheguem ao consciente de maneira minimizada ou disfarçada. Ressaltamos que as estratégias de defesa podem ser tanto de ordem individual quanto coletivas (DEJOURS, 2012b). Nesse sentido, observamos a manifestação de algumas estratégias de defesa, de ordem individual, utilizadas por Luiz, Equilibrista, Fernando e Ricardo, sendo possível sugerir o uso, em todos os casos, de pelo menos duas estratégias de defesas individuais. Entretanto, há também, particularidades a serem ressaltadas a respeito de cada caso.

As falas de Luiz, Equilibrista, Fernando e Ricardo, por vezes, indicam o processo de sublimação. Considerada uma estratégia individual de defesa ou mecanismo de defesa, a sublimação diz respeito a recorrer a meios aceitáveis socialmente e/ou gratificantes como forma para resolução indireta de conflitos internos (VAILLANT, 2000; FREUD, [1936]2006; CANÇADO; SANT'ANNA, 2013). Destacamos, nesse sentido, os casos de Equilibrista e Fernando, quando os mesmos relatam que trabalhar na área artística, além de lhes proporcionar prazer, os auxilia a lidar com inúmeras situações sofríveis de seu cotidiano e de seu trabalho.

Assim como a sublimação, é possível notar o uso de racionalização em todos os casos estudados. A racionalização diz respeito à utilização de explicações racionais para tentar justificar comportamentos, atitudes ou crenças que, de outros modos poderiam, ou não, ser considerados inaceitáveis (VAILLANT, 2000; FREUD, [1936]2006; CANÇADO; SANT'ANNA, 2013). Na fala de Fernando, a racionalização pode ser vislumbrada quando o artista fornece uma explicação para as ocasiões que o constrangem, quando ele se submete às situações contrárias à sua preferência ou valores pessoais. "Eu sou um prestador de serviço. A minha responsabilidade é isso, estudar e cumprir aquilo para que me contrataram”. Além da sublimação e racionalização, as falas dos entrevistados apontam também para o uso da 
somatização, principalmente em Ricardo e Fernando, os quais possuem mais tempo de atuação na atividade artística.

Enquanto estratégia de defesa individual, a somatização implica na tradução, de maneira desproporcional, em sintomas físicos e conflitos intrapsíquicos (VAILLANT, 2000; FREUD, [1936]2006; CANÇADO; SANT'ANNA, 2013). No caso de Fernando, a somatização se faz presente em sua fala, quando o artista relata que em momentos conturbados, como a falta de apoio no início de sua carreira, frequentemente apresentava sintomas depressivos, azia e dor no estômago. Em relação a Ricardo, podemos pensar na somatização, quando o artista discorre que frequentemente apresenta insônia, stress e problemas gastrointestinais.

A partir do conteúdo transmitido por Ricardo, é possível considerar também o uso da hiperatividade no trabalho como estratégia de defesa individual. A hiperatividade, ou o trabalho compulsivo, de acordo com Dejours (2004) e Marzano (2004), são defesas contra o sofrimento no trabalho que permitem ao trabalhador manter-se ocupado, sem entrar em contato com dimensões que lhe angustiam no trabalho. Diante da frequente intensificação que Ricardo realiza em seu ritmo de trabalho, sem a realização de pausas entre as atividades desempenhadas, percebemos o uso de algumas dinâmicas que se aproximam da hiperatividade, ou trabalho compulsivo, abordados por Dejours (2004) e Marzano (2004).

No conteúdo trazido à luz por Luiz, além da racionalização e sublimação, podemos pensar no uso do humor. Considerado um mecanismo de defesa, o humor diz respeito a expressar experiências dolorosas de maneira espontânea e sem aparente incômodo, para si e para quem está ao redor (VAILLANT, 2000; FREUD, [1936]2006; CANÇADO; SANT'ANNA, 2013). O uso do humor, se faz presente na fala de Luiz, ao referir que diante da pouca presença de público em seus espetáculos - circunstância observada ao acompanharmos uma de suas apresentações realizadas no centro cultural -, ele e seus colegas de trabalho costumam rir da situação. Nas palavras de Luiz: “(...) a gente faz graça, assim "chegou um, agora dois." Fazer o que? Vou chorar?" No que concerne à existência de patologias associadas ao trabalho destacamos, principalmente em Equilibrista e Fernando, a percepção de patologias da sobrecarga, tais como: lesões musculares e tendinite.

Apresentadas as situações referentes ao sofrimento no trabalho dos artistas participantes desta pesquisa, bem como as estratégias de defesas, sintomas e patologias, cabenos refletir agora, a respeito de como caracterizar o sofrimento por eles vivenciado. Frente ao exposto, consideramos presente em seu cotidiano, tanto o sofrimento criativo quanto o patogênico. Entretanto, Luiz e Equilibrista, artistas com menor tempo de trabalho exclusivo 
na arte do que Fernando e Ricardo, apresentam quadros em que o sofrimento criativo tende a prevalecer sobre o patogênico. Especialmente, no caso de Luiz, onde duas das três estratégias de defesa relacionadas ao artista - sublimação e humor -, são classificados por Vaillant (2000), como mecanismos de defesa mais maduros. Já Fernando e Ricardo, artistas que mantêm suas famílias com renda obtida exclusivamente da arte e que atuam no campo artístico por mais tempo que Luiz e Equilibrista, apresentam quadros em que o sofrimento patogênico tende a prevalecer sobre o sofrimento criativo. Sustentamos tal afirmação diante das estratégias de defesas relacionadas aos artistas e aos sintomas e patologias por eles associados aos seus trabalhos.

\section{CONSIDERAÇÕES FINAIS: ESBOÇOS DE UMA REFLEXÃO SEM FIM}

Buscamos neste estudo, compreender e analisar as possíveis relações existentes entre o contexto de trabalho no setor cultural, e vivências de prazer-sofrimento dos trabalhadores nele inseridos, tendo em vista o processo de mercantilização da cultura. Para tal feito, seguimos pressupostos baseados na Psicodinâmica do Trabalho. Ressaltamos que o aporte teórico da psicodinâmica do trabalho, oferece uma grande contribuição ao estudo da relação entre subjetividade e trabalho, e se constitui como uma boa alternativa para a realização de tais discussões nos estudos organizacionais.

Participaram desta investigação quatro artistas atuantes na região da grande Florianópolis/SC. É válido elucidar que os quatro sujeitos trabalhavam em distintas áreas e possuíam diferentes tempos de atuação na esfera artística. Circunstância, que possibilitou que observássemos, entre eles, situações semelhantes e divergentes. Nessa perspectiva, salientamos que a atividade artística na região estudada tende a ser caracterizada como uma forma de trabalho em que há: um forte engajamento subjetivo; ausência de vínculos formais de trabalho; pouca ou nenhuma presença de benefícios trabalhistas assegurados pela Consolidação das Leis Trabalhistas (CLT); realização de atividades e/ou projetos com mais de um cliente ao mesmo tempo; variabilidade de renda; ritmo de trabalho intenso; vivência de uma fronteira porosa entre vida pessoal e trabalho; inseguranças financeiras; e existência de vínculos empregatícios (formais/informais) remotos com organizações.

As vivências de prazer no trabalho artístico foram relacionadas: ao reconhecimento pelo trabalho desenvolvido; ao fato de exercer a profissão de livre escolha; ao processo de criação envolvido na atividade artística; à liberdade para criar; às experiências exitosas diante de circunstâncias imprevistas. No que diz respeito às vivências de sofrimento no trabalho 
artístico, destacamos que as mesmas podem ser relacionadas a situações como: não compreensão do fazer artístico como um trabalho por parte de sujeitos que não pertencentes à esfera artística; ausência de vínculos formais de trabalho; inexistência ou pouca presença de benefícios trabalhistas assegurados pela CLT; inseguranças financeiras; ausência de reconhecimento da beleza do trabalho desenvolvido; ritmo de trabalho intenso e limitada liberdade para criar.

Observamos também, estratégias de defesa de ordem individual nos participantes deste estudo. Salienta-se que em todos os casos, notou-se o uso da sublimação de racionalização. Além destas, percebeu-se em Luiz a utilização do humor e em Ricardo e Fernando, nos sujeitos com maior tempo de trabalho na esfera artista, a presença da somatização. No que concerne à existência de patologias associadas ao trabalho destacamos, principalmente em Equilibrista e Fernando, a percepção de patologias da sobrecarga, tais como: lesões musculares e tendinite

Ao consideramos as vivências de prazer e sofrimento descritas pelos protagonistas desta investigação, bem como no modo como engajavam no trabalho, empregando e expandindo sua subjetividade fazendo o uso dos elementos constituintes da mobilização subjetiva, tornou-se possível a percepção de que, de maneira geral, a atividade artística é estruturante aos sujeitos. A partir dos casos analisados e do referencial teórico adotado, observamos também, que ainda que a atividade artística por intermédio de sua potência criadora demonstre o poder constituinte do trabalho vivo e seja considerada como uma possibilidade de trabalho não alienado (DEJOURS, 2012b), nas sociedades subjugadas aos ditames do mercado, os artistas encontram-se submetidos e/ou influenciados pela lógica mercadológica (MARX; ENGELS, [1848]2014). Acreditamos que tal submissão e/ou influência não permanece isenta de consequências deletérias ao artista enquanto trabalhador.

Nesse sentido, evidenciamos que o processo de mercantilização da cultura parece influenciar na vivência de sofrimento destes trabalhadores, tendo em vista, que a absorção de características mercantis pelo setor cultural, tende a limitar a liberdade de criação dos artistas, e proporcionar a existência de um ambiente de competições, por busca de espaço e destaque. A tensão decorrente do ambiente de competições, por sua vez, tende a dificultar o reconhecimento da beleza do trabalho, tolher a existência de relações de cooperação e a manutenção de um espaço de discussão, bem como a legitimação de ações concernentes ao uso da inteligência prática, fatos que podem dificultar a subversão do sofrimento em prazer e possibilitar a instalação do sofrimento patogênico. 
No que concerne ao contexto de trabalho artístico na região da grande Florianópolis, não consideramos que há uma vasta diferença em relação ao apoio à cultura, e ao desenvolvimento de políticas culturais do restante do país, e principalmente ao estado de Santa Catarina. Entendemos que possa existir nesta região, assim como no estado de Santa Catarina, uma realidade precária em termos de apoio à cultura por meio do desenvolvimento de políticas públicas, no entanto, acreditamos que ela não se distancia muito da realidade observada nos demais estados do Brasil. Desse modo, enfatizamos o papel do Estado no desenvolvimento de políticas culturais e formas de financiamento ao trabalho artístico, observando a necessidade de democratização ao acesso à tais políticas e a continuidade das mesmas (RUBIN, 2007; 2015). Todavia, a partir do exposto pelos sujeitos participantes deste estudo, sublinhamos que da mesma maneira em que há necessidade de mudança na criação e na trajetória das políticas culturais nacionais, acreditamos que é essencial a existência de um maior engajamento e mobilização política dos artistas, em relação ao seu contexto de trabalho, de maneira a reafirmar sua atividade enquanto um trabalho e buscar condições de trabalho adequadas para a sua realização.

\section{REFERÊNCIAS}

ABRAHAM, Yves-Marie. L'entreprise est-elle nécessaire? In: DUPUIS, Jean-Pierre (org.). Sociologie de l'entreprise. Montréal: Gaëtan Morin Editeur, 2006, p. 323-374.

ANTUNES, R. Adeus ao trabalho? Ensaios sobre as metamorfoses e a centralidade do mundo do trabalho. 16 Edição. São Paulo, Cortez, 2015.

ASSIS, D. T. F. O trabalho em uma banda de Blues: uma abordagem psicodinâmica. Dissertação de Mestrado. Mestrado em Psicologia. Goiânia: Pontifícia Universidade Católica de Goiás, 2008.

BANKS, M; GILL, R.; TAYLOR, S. (Ed). Theorizing cultural work: labour, continuity and change in the cultural and creative industries. Nova Iorque: Routledge,2013.

BARDIN, L. Análise de Conteúdo. São Paulo: Edições 70, 2016.

BENDASSOLI, P. F. Significado do trabalho e carreira artística. FGV. Rio de Janeiro, p. 44. 2009.

BENDASSOLI, P. F.; BORGES-ANDRADE, J. E. Significado do trabalho nas indústrias criativas. RAE, v.51 n.2, p. 143-159, 2011.

BENHAMOU, F. A economia da cultura. São Paulo: Ateliê Editorial, 2007.

BRANT, L. O poder da cultura. São Paulo: Petrópolis, 2009. 
BRASIL, Ministério da Cultura. Cultura em números: anuário de estatísticas culturais. $2^{\mathrm{a}}$ Edição. Brasília: MinC, 2010.

BUENO, M. As vivências dos escritores literários em relação ao seu trabalho: uma análise psicodinâmica do trabalho. Tese de Doutorado. Doutorado em Psicologia. Goiânia: Pontifícia Universidade Católica de Goiás, 2012.

CANÇADO, V. L; SANT'ANNA, A. de S. Mecanismos de Defesa. In: VIEIRA, F. de O.; MENDES, A. M.; MERLO, A. R. C. (Org.). Dicionário critico de gestão e psicodinâmica do trabalho. Curitiba: Juruá, 2013. p. 249- 254.

CTAC, Centro Técnico de Artes Cênicas. Santa Catarina. Disponível em: http://www.ctac.gov.br/teatro/resultpesqteatro.asp? $m a p=1 \& u f n m=S a n t a+C a t a r i n a \& U F=S C \&$ first=Localidade\&second=Espa\%E7o+c\%EAnico. Acesso em: 12 mar. de 2017.

DEJOURS, J. C. A banalização da injustiça social. $2^{\text {a }}$ ed. Rio de Janeiro: Fundação Getúlio Vargas, 1999.

DEJOURS, J. C. Activisme professionnel: masochisme, compulsivité ou aliénation?

Travailler, $\mathrm{n}^{\mathrm{0}}$ 11, p. 25-40, 2004.

DEJOURS, J. C. A Sublimação, entre prazer e sofrimento no trabalho. Revista Portuguesa de Psicanálise. Lisboa, v.33, n.2, p.9-28, 2013.

DEJOURS, J. C. Da psicopatologia à psicodinâmica do trabalho. LANCMAN, S;

SZNELWAR, L. I. (Orgs.). Rio de Janeiro: Fiocruz, 2008b.

DEJOURS, J. C. O fator humano. Rio de janeiro: FGV, 1997.

DEJOURS, J. C. Trabalho vivo: Sexualidade e trabalho (Tomo I). Brasília: Paralelo 15, 2012a.

DEJOURS, J. C. Trabalho vivo: Trabalho e emancipação (Tomo II). Brasília: Paralelo 15, $2012 b$.

DEJOURS, J. C. ABDOUCHELI, E. , JAYET, C. Psicodinâmica do trabalho: contribuições da escola Dejouriana à análise da relação prazer, sofrimento e trabalho. $1^{\text {a }}$ Edição. São Paulo: Atlas, 2014.

FERREIRA, J. B. Do poema nasce o poeta: criação literária, trabalho e subjetivação. Rio de Janeiro: 7 Letras, 2011a.

FERREIRA, J. B. O poder constituinte do trabalho vivo: análise psicodinâmica da criação literária. 2011. 203 f. Tese de Doutorado em Psicologia Social do Trabalho e das Organizações.203 f. Universidade de Brasília, Brasília, 2011 b. 
FERREIRA, J. B. Patologias da Solidão. In: VIEIRA, F. de O.; MENDES, A. M.; MERLO, A. R. C. (Orgs.). Dicionário critico de gestão e psicodinâmica do trabalho. Curitiba: Juruá, 2013. p. 275- 279 .

FUNDAÇÃO GETÚLIO VARGAS (FGV). A cultura na economia brasileira. Rio de Janeiro: FGV, 2015.

FREUD, A. O ego e os mecanismos de defesa [1936]. Porto Alegre: Artmed, 2006.

FREUD, S. O mal-estar na civilização [1930]. São Paulo: Penguin Clasics Companhia das Letras, 2011.

GAULEJAC, V. de. Gestão como doença social: deologia, poder gerencialista e fragmentação social. São Paulo: Ideias \& Letras, 2014.

HOPE, S; RICHARDS, J. Loving work: Drawing attention to pleasure and pain in the body of the cultural worker. European Journal of Cultural Studies, v. 18, n. 2, p. 117-141, Apr. 2015.

INSTITUTO BRASILEIRO DE GEOGRAFIA E ESTATÍSTICA (IBGE). Perfil dos estados e municípios brasileiros. Pesquisa de informações básicas estaduais; Pesquisa de informações básicas municipais, 2014. Rio de Janeiro: 2015.

LIMA, V. S. O trabalho de artistas de um grupo de comédia: Análise psicodinâmica do prazer e do enfrentamento do sofrimento. Dissertação de Mestrado em Psicologia Social, do Trabalho e das Organizações. Brasília: Universidade de Brasília, 2009.

LOACKER, B. Becoming 'culturpreneur': How the 'neoliberal regime of truth' affects and redefines artistic subject positions. Culture and Organization, Abingdon-UK, v. 19, n. 2, p. 124-145, 2013.

LHUILIER, D. Trabalho. Psicologia \& Sociedade, Porto Alegre, v.25, n.3, p.483-492. 2013. MARX, K. Manuscritos econômicos-filosóficos [1844]. São Paulo: Martin Claret, 2017. MARX, K.; ENGELS, F. Manifesto do Partido Comunista [1848]. 2. ed. Rio de Janeiro: Ed. Petrópolis, 2014.

MARZANO, M. Travail et compulsif apagamento de la subjectivité: L'hyperactivité comme fuite. Travailler, Paris, v 1, n. 11, p. 7-24, 2004.

MENDES, A. M. (org.). Psicodinâmica do trabalho: teoria, método e pesquisas. São Paulo: Casa do Psicólogo, 2007.

MENDES, A. M; ARAÚJO, L. K. R. Clínica psicodinâmica do trabalho: o sujeito em aço. Curitiba: Juruá, 2012. 
MENDES, A. M.; MULLER, T. C. Prazer no Trabalho. In: VIEIRA, F. de O.; MENDES, A. M.; MERLO, A. R. C. (Orgs.). Dicionário critico de gestão e psicodinâmica do trabalho. Curitiba: Juruá, 2013. p. 289- 292.

MENGER, P-M. Retrato do artista enquanto trabalhador: metamorfose do Capitalismo. Lisboa: Editora Roma, 2005.

MERLO, A. R. C.; MENDES, A. M. Perspectivas do uso da psicodinâmica do trabalho no Brasil: teoria, pesquisa e ação. Cadernos de Psicologia Social e do Trabalho, v. 12, n. 2, p.141-156, 2009.

MERLO, A. R. C. Psicodinâmica do trabalho. In: JACQUES, M. da G. C.; CODO, W. (Orgs.). Saúde mental \& trabalho: leituras. São Paulo: Vozes, 2002. p. 130-142. MONTEIRO, J. K.; MORAES, R. D.; MENDES, A. M.; MERLO, A. R. C. Psicodinâmica do trabalho no Brasil: práticas, avanços e desafios. Curitiba: Juruá, 2017.

PAES DE PAULA, A. P. Tragtemberg revisitado: as inexoráveis harmonias administrativas e as burocracias flexíveis. Revista de Administração Pública, v. 36, n. 1, p. 127-144, jan./fev. 2002.

PIRES, R. V. Eu suporto tudo só para me sentir artista: as vivências dos profissionais de uma companhia de teatro em relação ao seu trabalho, uma abordagem psicodinâmica. Tese de Doutorado - Programa Stricto sensu em Psicologia, Pontifícia Universidade Católica de Goiás, Goiânia, 2011.

POLANY, Karl. A grande transformação: as origens de nossa época. Rio de Janeiro: Campus, 2000.

RAMOS, A. G. A nova ciência das organizações: uma reconceituação das riquezas das nações. Rio de Janeiro: FGV, 1989.

RODRIGUES, M. S.; SILVA, R. C.; A estrutura empresarial nos clubes de futebol. Organ. Soc., Salvador, v. 16, n. 48, p. 17-37, Mar. 2009.

RODRIGUES, M. S.; SILVA, R. C.; DELlAGNELO, E. H. L. O processo de empresarização em organizações culturais brasileiras. Revista Pensamento Contemporâneo em Administração, v. 8, n. 1, p. 66-85, 2014.

RUBIM, A. A. C. Políticas culturais no Brasil: tristes tradições, enormes desafios. Salvador, 2007.

RUBIM, A. A. C. Políticas Culturais no Governo Dilma: Patamar Rebaixado. In: RUBIM, A. A. C., BARBAlHO, A.; CALABRE, L. (org). Políticas culturais no Governo Dilma. Salvador: EDUFBA, 2015. p.11-31. 
SANTOS, E. A. O trabalho dos bailarinos profissionais de uma companhia de dança contemporânea: uma perspectiva psicodinâmica. Dissertação de Mestrado em Psicologia. Pontifícia Universidade Católica de Goiás, Goiânia, 2008.

SEGNINI, M.P. Prazer e sofrimento notrabalho artístico em dança.

2010.156p.Dissertação (mestrado em Ciências da Reabilitação) Faculdade de Medicina da Universidade de São Paulo. São Paulo. 2010.

SEGNINI, M. P.; LANCMAN, S. Sofrimento psíquico do bailarino: Um olhar da psicodinâmica do trabalho. Revista Laboreal, v.7, n.1, 2011.

TRANSFORM. Producción cultural y prácticas instituyentes: líneas de ruptura en la crítica institucional. Traficantes de Sueños: Madrid, 2008.

THROSBY, D. Defining the artistic workforce: the Australian experience. Poetics, 28, p. 255-271, 2001.

VAILlANT, G. Adaptative Mental Mechanisms: Their Role in a Positive Psychology. American Psychologist, v. 55, n. 1, p. 89-98. Jan. 2000.

VASCONCELOS, A. C. L. Inteligência Prática In: VIEIRA, F. de O.; MENDES, A. M.; MERLO, A. R. C. (Org.). Dicionário critico de gestão e psicodinâmica do trabalho. Curitiba: Juruá, 2013. p. 237 - 242. 